\title{
Environmental protection through environmental services payments
}

\author{
Viviane Farias Silva, Wanessa Regina Geraldo Lima, Carlos Vailan Castro bezerra, Vera Lucia \\ Antunes Lima e José Geraldo Vasconcelos Baracuhy \\ Universidade Federal de Campina Grande, Campina Grande, MG, Brasil \\ flordeformosur@hotmail.com; wanessaregina@gmail.com; carlosuailan@hotmail.com; \\ antunes.lima@gmail.com; geraldo.baracy@yahoo.com
}

\begin{abstract}
To provide goods and services to human's ecosystems need water like fish, timber, food, grains, among others. Similarly, are responsible for important services for the preservation of the quality and quantity of water available, such as the supply and maintenance of water flows and smoothing of natural disasters related to water, such as floods and droughts. This work was carried out to explain why the existence of this type of payment services in the pursuit of environmental protection exercised in several countries including environmental Brazil, based on the location of cases of payment for environmental services. Some countries have already practiced the payment for environmental services and the majority of services is related to water. Environmental service providers whose main goal that the business is profitable and remains. Payment for environmental service exists as an incentive to conserve the environment so profitable to the owner of rural land or forests ale smallholders and farmers.
\end{abstract}

Keywords: Water quality, Vegetation. Ecosystem. 


\section{Introduction}

Humanity since your appearance is dependent on the environment. Natural resources like water, air and sunlight are of extreme importance for the survival of life on Earth. After years of indifference to the environment comes the practice of sustainable development, with a view to interacting human beings to the environment. Thus deployed means of protecting natural resources to ensure the environmental services provided to the population.

Environmental services is the performance of activities provided by natural ecosystems for the benefit of human society. Second Whately and Hercowitz (2008) environmental services are understood as the indirect benefits generated by natural resources or the systemic properties of the interrelationships between these resources and the nature, as production and availability of drinking water; climate regulation; biodiversity; landscape; soil fertility etc.

To provide goods and services for human beings, ecosystems need water like fish, wood, food, grains, among others. Likewise, are responsible for important services for the preservation of the quality and quantity of water available, as the maintenance of supply and water flows and smoothing of natural disasters related to water, such as floods and droughts.

The valuation of environmental services is a way to encourage the conservation of the environment. These services have a price, get paid directly, such as the production of food or water supply. However for various environmental services there are no market prices due to the complexities of quantifying your importance. There are a few ways of payment for environmental services (PSA), being the most frequent direct payment. In these cases, the Government or the private sector pays landowners for adopting techniques able to solve an environmental problem. As well as the payment can become a form of incentive or certificate.

The payment of environmental services (PSA) is a form that both the producers and owners of land using sustainable methods for saving the environment. Being financial transfers to beneficiaries of environmental services to those who, because of practices that conserve nature, provide these services. The PSA can promote conservation through financial incentives for providers of environmental services (BRAZIL, 2009).

In Latin America, Costa Rica is the country earlier in terms of public policies for environmental protection and use of mechanisms of PSA focused on watershed management (LANDELL-MILLS and PORRAS, 2002). However other countries such as Nicaragua, Honduras, Ecuador and Brazil also have advanced in this theme tied experiences (ANA, 2010; KOSOY et al., 2006; WUNTER and ALBAN, 2008).

Currently, programs that use the PSA are considered by FAO (2004) promising mechanisms for the financing of environmental protection and restoration, as well as a way to complement and strengthen existing regulations.

The present work was carried out with the objective of explaining why the existence of this environmental services payment mode that is exercised in various countries including Brazil.

\section{Methodology}

This article was based on the location of environmental services payment situations. The information was generated by searching the internet. From these empirical examples has been classified in accordance with the environmental service provided, the amount paid, identifying the agents and the justification of the payment.

For each situation sought to answer the following questions:

the) What is the environmental service is being provided?

(b)) How much are you getting paid?

(c)) Identification of the two agents, who provides the service and who pays?

(d)) Why is this occurring?

Each of these questions is answered in accordance with the survey data. All the data were organized in a framework for a better viewing and discussion.

\section{Results and Discussion}

Some countries have already practiced the payment for environmental services and in table 1 one can see that is a widely used alternative to various environmental services.

As you can notice in table 1 that most of the services provided is related to water. Because the use of chemical fertilizers, deforestation, monoculture forests, use of pesticides, sewage released without prior treatment into rivers, are some of the causes that directly or indirectly affect the quality, quantity and regularization of water flow.

One of the reasons for the decrease in the amount of water and siltation of rivers is the lack of plant cover. Decreasing the infiltration, increasing the impact of rain on the ground causing erosion as a result assoreando the rivers. Water pollution is directly linked to sewers released without prior treatment apart from frequent use of chemical fertilizers and pesticides that 
are transported by rain to rivers.

In France the company Nestlé Waters water bottling due to decrease of vegetation in permanent preservation areas in tributaries there was a reduction in the quality and quantity of water, so to ensure good quality water paid for the service provided by dairy farmers and forest owners to the reforestation of the area. So the company today has one of the best natural bottled waters.

Investing in upstream producers, Nestle has funded improvements in properties such as construction of terracing in level and vegetation recovery. Invested in the training of producers and also funded equipment to modernize the production, combating diffuse pollution and improving environmental quality.

Table 1-Environmental services payment situations in some countries.

\begin{tabular}{|c|c|c|c|c|c|c|}
\hline \multirow[b]{2}{*}{$\mathrm{N}^{\mathrm{o}}$} & \multirow[b]{2}{*}{ Country } & \multirow{2}{*}{$\begin{array}{c}\text { Environmental } \\
\text { service provided }\end{array}$} & \multirow[b]{2}{*}{ Value of PSA } & \multicolumn{2}{|c|}{ Agents } & \multirow{2}{*}{ Justification the use of PSA } \\
\hline & & & & Buyer & Supplier & \\
\hline 1 & Brazil & $\begin{array}{l}\text { Management of } \\
\text { water resources }\end{array}$ & $\begin{array}{c}100 \text { UFEX (169.00 R\$) } \\
\text { per hectare/year }\end{array}$ & $\begin{array}{l}\text { Municipality of } \\
\text { extreme/MG. }\end{array}$ & Landowners. & $\begin{array}{l}\text { The water that comes out of } \\
\text { micro-basins of the possessions } \\
\text { are one of the main water } \\
\text { sources. }\end{array}$ \\
\hline 2 & Brazil & $\begin{array}{l}\text { Management of } \\
\text { water resources }\end{array}$ & $\mathrm{R} \$ 263.7$ hectare/year & $\begin{array}{l}\text { Mitsubishi } \\
\text { Foundation }\end{array}$ & Landowners. & $\begin{array}{l}\text { Strengthening your brand for } \\
\text { your involvement in social and } \\
\text { environmental issue }\end{array}$ \\
\hline 3 & Colombia & $\begin{array}{l}\text { Improvements } \\
\text { of base flow and } \\
\text { sedimentation } \\
\text { reduction in } \\
\text { irrigation canals }\end{array}$ & $\begin{array}{l}\text { Members of the } \\
\text { Association } \\
\text { pay voluntarily a fee } \\
\text { of } \$ 1.5-\$ 2 \text { per liter of } \\
\text { water, in addition to an } \\
\text { existing rate of } \$ \$ 0.5 \\
\text { per litre. }\end{array}$ & $\begin{array}{l}\text { Association } \\
\text { of sprinklers; } \\
\text { Government } \\
\text { agencies }\end{array}$ & $\begin{array}{l}\text { Owners } \\
\text { deprived of } \\
\text { forest areas } \\
\text { located in the } \\
\text { upper part of } \\
\text { the basin. }\end{array}$ & $\begin{array}{l}\text { Reforestation, erosion control, } \\
\text { protection of springs and } \\
\text { watercourses, and } \\
\text { development of } \\
\text { basin communities }\end{array}$ \\
\hline 4 & Costa Rica & $\begin{array}{l}\text { Regularity of } \\
\text { water flow for } \\
\text { hydroelectricity }\end{array}$ & $\begin{array}{l}\text { Landowners protecting } \\
\text { their forests receive } \\
\$ 45 \text { dollars/ha/year; } \\
\text { those who manage } \\
\text { their forests in a } \\
\text { sustainable way } \\
\text { receive } \$ \$ 70 / \text { ha/ } \\
\text { year, and those who } \\
\text { reflorestam } \\
\text { his land receive } \$ \\
\$ 116 / \text { ha/year. }\end{array}$ & $\begin{array}{l}\text { Hydroelectric } \\
\text { Power Plant, } \\
\text { Government of } \\
\text { Costa Rica and } \\
\text { Local NGO }\end{array}$ & $\begin{array}{l}\text { Private owners } \\
\text { of land located } \\
\text { in the upper } \\
\text { part of the } \\
\text { basin. }\end{array}$ & $\begin{array}{l}\text { The increase in forest cover in } \\
\text { private land; expansion of forests } \\
\text { through the protection and } \\
\text { regeneration. }\end{array}$ \\
\hline 5 & France & $\begin{array}{l}\text { Drinking water } \\
\text { quality }\end{array}$ & $\$ 230.0$ per hectare/year & $\begin{array}{l}\text { Nestlé Waters. } \\
\text { Bottling of } \\
\text { mineral water }\end{array}$ & $\begin{array}{l}\text { Farmers and } \\
\text { forest owners }\end{array}$ & Reforestation. \\
\hline 6 & Australia & $\begin{array}{l}\text { Reduction of } \\
\text { salinity of the } \\
\text { water }\end{array}$ & $\begin{array}{l}\text { Sprinklers pay } \$ 40 \\
\text { dollars per hectare } \\
\text { a year, } 10 \text { years, to the } \\
\text { forests } \\
\text { NSW State, a } \\
\text { government agency } \\
\text { that uses the revenue to } \\
\text { do reforestation on } \\
\text { private and public } \\
\text { lands, } \\
\text { maintaining the rights } \\
\text { of forest management. }\end{array}$ & $\begin{array}{l}\text { State Forests } \\
\text { in New South } \\
\text { Wales (NSW) }\end{array}$ & $\begin{array}{l}\text { Association } \\
\text { sprinklers } \\
\text { agricultural }\end{array}$ & $\begin{array}{c}\text { Reforestation } \\
\text { on a large scale, } \\
\text { including fertilization } \\
\text { dessalinizadas plants, trees and } \\
\text { other vegetations } \\
\text { perennials for deep roots }\end{array}$ \\
\hline 7 & USA & Water quality & $\begin{array}{l}1.5 \text { billion dollars for } \\
10 \text { years }\end{array}$ & $\begin{array}{l}\text { Government of } \\
\text { New York }\end{array}$ & $\begin{array}{c}\text { Rural } \\
\text { Producers }\end{array}$ & Watershed protection. \\
\hline 8 & Honduras & Water quality & $\$ 16.5$ to $5.5 /$ ha/year & Government & Landowners & $\begin{array}{l}\text { River basin protection Ridges } \\
\text { that supplies the city }\end{array}$ \\
\hline 9 & Brazil & $\begin{array}{l}\text { Water quality } \\
\text { maintenance }\end{array}$ & $\begin{array}{c}\mathrm{R} \$ 175 \text { to } 578 \text { for three } \\
\text { years }\end{array}$ & $\begin{array}{l}\text { City of Joinville- } \\
\text { Santa Catarina }\end{array}$ & Landowners & $\begin{array}{l}\text { Recovering riparian forests of } \\
\text { Cubatão basin which supplies } \\
\text { the city }\end{array}$ \\
\hline 10 & $\begin{array}{l}\text { Brazil- } \\
\text { Paraguay }\end{array}$ & $\begin{array}{l}\text { Maintaining the } \\
\text { quality and flow } \\
\text { regularization }\end{array}$ & Technical assistance & $\begin{array}{c}\text { Itaipu } \\
\text { hydroelectric }\end{array}$ & Farmers & $\begin{array}{l}\text { Reducing the impacts of } \\
\text { agricultural production in the } \\
\text { waters of the reservoirs. }\end{array}$ \\
\hline
\end{tabular}


According to Perrot-Maître (2006), the company chose to invest in preserving your source of resources, rather than look for another place to capture, since water produced in that region has unique properties and due to their qualities built a specific market. Change the water source would be a risk because the company could lose your consumer market.

Spending on the program, according to Postel et al. (2005), are on the order of 1.5 billion dollars over 10 years, from fees levied on water bills, in addition to titles. In the first five years of the program, the city bought 118,700 ha, totaling $\$ 94$ million, expenditures and part of this area was opened to the public for recreation. Other 960 ha of the basins were destined for slavery, that is, the owners pledged to maintain protected forest areas in Exchange for payments by the opportunity cost of the land.

The supply of this metropolis is guaranteed by the maintenance of water quality for rural producers in the region, in a perimeter of up to 200 kilometers from the Mainland, and such producers receive cash for the adoption of appropriate environmental practices in the watershed of the city providers give away having achieved a favorable solution through reforestation and water contamination not herd animals excrement.

In the case of agriculture as a provider of services for the protection of watersheds, the literature is less extensive, but virtually all the services provided by forests can potentially be found in agricultural areas. Some experiences of PSA use a combination of uses of the soil which may receive payments, including agriculture and forestry, such as the case of the program of New York City (LANDELLMILLS and PORRAS, 2002), and the schema in Jesús de Otoro, Honduras (KOSOY et al., 2006). Already in other cases, only the conservation agriculture is contemplated in the diagrams (ANTLE and VALDIVIA, 2006). The review on the topic of PSA in river basins, FAO (2004) States specific studies are required to include agricultural land in PSA schemes.

The watershed protection experience of the city of New York is perhaps the best known case of PSA for watershed protection (LANDELL-MILL and PORRAS, 2002, POSTEL and THOMPSON JR., 2005). Rather than invest in the construction of a water treatment plant to meet the requirements of the EPA, the city of New York began a comprehensive program of conservation and restoration of the 2 bowls where water is removed for $90 \%$ of the population, the Catskills and Delaware (POSTEL and THOMPSON JR., 2005).

The hydroelectric Itaipu provides technical assistance to farmers to maintain quality and flow regularization with the reduction of the impacts of agricultural production in the waters of the reservoirs. Being a way to encourage paying a different form of payment offering technical assistance at no cost to farmers of the region.

In Brazil in the city of extreme in Minas Gerais, through a municipal law the conservative water project aimed to preserve the fountains and springs in the municipality located on the watershed of the possessions. The watershed waters comprise one of the major water sources of the Cantareira system, which supplies the metropolitan region of São Paulo.

The Conservative Design of the waters was established by law in the mining town of extreme, at the end of 2005 . The goals of the project are to promote soil conservation, restore riparian forests and legal reserves, and adequate environmental sanitation in rural properties (EXTREME, 2005). After a year of the launch of the project, the NGO Conservation International, signed a deal with the city to give technical and financial support (THE NATURE CONSERVANCY-TNC, 2007).

The results of the conservative project of water (MG) pointed out the participation of 60 land owners in the municipality in the program, totaling 1,393.49 hectares benefited, receiving an amount that varies from 75 to R\$ $169 \mathrm{R} \$$ per hectare per year for soil conservation practices and maintenance of forests, including the adoption of soil conservation practices and link roads, with the purpose of chilling and planting 120,000 trees in properties.

The experience on a smaller scale is being done in Joinville, Santa Catarina. The City Hall, through the Municipal Foundation of your Environment (FUNDEMA) and with the support of Joinville Water Company and a local University, is paying farmers in the watershed areas of the city, the Rio Cubatão. The program, called Environmental financial compensation System, aims to recover the riparian forests of the Cubatão. Are already participating in the 13 Properties System upstream of the point of Joinville Water Company capture, and 13 more are expected to still be included. The properties receive $175 \mathrm{R} \$$ to 578 , for three years, depending on the size and area of forest (FUNDEMA, 2017).

In table 1 that the majority of buyers of ecosystem services is the Government, private institutions and some NGOs. As the main suppliers are landowners, private and rural as well as farmers and ranchers. There is not yet a fixed value for a given environmental service provided, some are considered priceless.

Environmental service providers have as main purpose the business is profitable or remains. Certainly environmental conservation is only a consequence of profitability. But also buyers of services aimed at the improvement of some environmental service is being harmed and that over time can cause financial damage to the same.

Soon note the importance of environmental payment at the time who provides needs a way to survive as who buys pay to improve environmental and service the entire ecosystem in the area.

Companies such as Mitsubishi Foundation pay landowners to use a proper management of water resources only for strengthening of the brand in Brazil. These companies receive certificates for helping concerned about improving the environment. 


\section{Conclusion}

The environmental service payment exists as an incentive to conserve the environment cost-effectively to rural land owner or small forest owners and farmers. Becoming an alternative income for the suppliers of the environmental services provided.

\section{References}

NATIONAL WATER AGENCY. “Water producer program”. 2010. available at URL: < http://www.ana.gov.br/ produagua $>$. Accessed on 20 July 2013.

ANTLE, J. M. and VALDIVIA, R. O. Modelling the Supply of Ecosystem Services from Agriculture: minimum-date approach. Australian Journal of Agricultural and Resource Economics 50, p. 1-15, 2006.

BRAZIL. ANA - NATIONAL WATER AGENCY. Operating Manual water Producer program. Ana, Brasilia, 67 p., 2009.

EXTREME. Municipal law paragraph 2,100, of 21 December 2005. "Creates the Conservative Project of water, authorizes the Executive to provide financial support to landowners and other arrangements". Available at: <http:// www.valornatural.org.br/lei_n_\%202100.pdf>. Access in 8/3/13.

FAO, Payment Schemes for Environmental Services in Watersheds, Land and Water Discussion Paper 3. Rome, 2004.

FUNDEMA- Fundação Municipal do Meio Ambiente de Joinville. Available at: www.fundema.sc.gov.br. Access in 20/02/2017.

KOSOY et al. Payments for Environmental Services in Watersheds: Insights from acomparative study of three cases in Central America. Ecological Economics . Vol. 61, no. 2-3, pp. 446-455, mar, 2006.

LANDELL-MILLS, N. and PORRAS, I.T. Silver bullet or fools' gold? A global review of markets for forest environmental services and their impact on the poor. International Institute for Environment and Development (IIED), London, 2002.

PERROT-MAÎTRE, D. (2006). The Vittel payments for ecosystem services: the "perfect" PES case?. Instruments for sustainable private sector forestry series. International Institute for Environment and Development, London, 2002.

POSTEL, SL; THOMPSON JR; BARTON, H. 2005. Watershed protection: capturing the benefits of nature's water supply services. Natural Resources Forum, London, v. 29, n. 2, p. 98-108, 2005.

SCHERR, S.; ANDY, W.; and ARVIND, K. with contribution of Mira Inbar and Augusta Molar. 2004. "For Services Rendered: The Current Status and Future Potential of Markets for the Ecosystem Services Provided by Tropical Forests." Yokohama, Japan: International Tropical Timber Organization (p. 30-31).

TNC-THE NATURE CONSERVANCY. Available in: < www.nature.org/wherewework/southamerica/brasil/press/ press2776.html >. Access in 3/23/07.

WHATELY, M. and HERCOWITZ,M. Environmental services: knowing, valuing and caring: grants for watershed protection of São Paulo/Marussia Whately, Marcelo Hercowitz. -São Paulo: Instituto Socioambiental, 2008.

WUNDER, M. and ALBAN, M. Decentralized payments for environmental services: The cases of Pimampiro and PROFAFOR in Ecuador. Ecological Economics, v. 65, no. 4, p. 685-698., 2008. 